\title{
The Construction and Analysis of Financial Liberalization Index of China
}

\author{
Nie Lei, Shigui Tao* \\ Department of Finance, Nanjing Normal University, Nanjing, China \\ Email address: \\ 1371917933@qq.com (Nie Lei), sgtao008@sina.com (Shigui Tao) \\ ${ }^{*}$ Corresponding author
}

\section{To cite this article:}

Nie Lei, Shigui Tao. The Construction and Analysis of Financial Liberalization Index of China. International Journal of Business and Economics Research. Vol. 6, No. 4, 2017, pp. 48-52. doi: 10.11648/j.ijber.20170604.11

Received: May 11, 2017; Accepted: June 3, 2017; Published: July 13, 2017

\begin{abstract}
This paper reviews the literature on financial liberalization, defines financial liberalization as a comprehensive reflection of the following aspects: interest rate liberalization, credit control relaxation, measures to encourage competition, macro-prudential supervision, diversification of banking property rights, securities market reform, international financial liberalization. For the past five years, almost all the major events in the process of China's financial liberalization are sorted out and assigned, then this paper uses PCA to do empirical analysis and constructs CFLI(financial liberalization index of China).
\end{abstract}

Keywords: Financial Liberalization Index, China, Principal Component Analysis

\section{Introduction}

In 1973, McKinnon and Shaw proposed the "financial restraint" theory, and refer it as the liberalization of interest rates and government intervention to reduce. Later, many scholars have done this in-depth study, not only to build a financial liberalization evaluation index system, calculate the financial liberalization index, but also judged the multinational financial liberalization and even the level of financial market; Williamson \& Mahar (1998) further extends the content of financial liberalization to include liberalization of interest rates, elimination of loan controls, free access to financial services, respect for financial institution autonomy, privatization of state banks and liberalization of international capital flows aspect; Yi Fenfei and Ding Dan (2007) Define financial liberalization as the reduction of the degree of government administrative intervention and the establishment of the basis of market regulation role; Financial liberalization, in Zhuang Xiaojiu's view(2007), is defined as a comprehensive reflection of seven aspects: interest rate liberalization, credit control relaxation, entry barriers, banking autonomy, diversification of banking property rights, securities market reform, capital and current account opening; Bandiera (2000) used eight indicators of interest rate liberalization, credit guidance relaxation, encouraging competition, banking property reform, prudential supervision, reserve requirements, stock market liberalization and financial internationalization, and estimated 13 developing countries Liberalization index, and to judge the level of financial markets in these countries. This paper argues that financial liberalization is a dynamic process in which a country's financial system operates from a major change from government regulation to market power.

\section{Literature Review}

Through the extensive reading of the existing literature, this paper summarizes the measurement method as follows:

\subsection{Dichotomy}

That is, the sample is divided into two parts by time: "before" financial liberalization and "post-" financial liberalization period. Usually, it's from a few different scopes to examine the progress of a country's financial liberalization and check in which year all these scopes are fully open. Use this certain year as a demarcation point to set dummy variables, 0 for before the liberalization and 1 for after that. The Jaewoon et al. (2004) divided seven areas to examine the progress of financial liberalization in Korea, arguing that basic liberalization in all areas in 1996, with 96 years as a 
breakpoint to test financial liberalization of foreign financial constraints on Korean firms influences. Some of the literature uses a more precise approach, such as Montiel and Reihnart (1999) using 0, 1, 2 three values to measure.

\subsection{Rating Method}

Kaminsky et al.(2003) divided financial liberalization into three areas: liberalization of capital accounts, liberalization in the domestic financial sector and liberalization of the securities market. The world's 28 countries in accordance with these three aspects were classified as complete freedom, part of the freedom and not yet free three levels. When a country is completely free in at least two areas, and at least partly free in another field, it is said that the state finance is completely free and assigned a value of 1 ; when a country is at least partly in two areas, This country can be called the financial part of the freedom, assigned to 2; otherwise it is called the country in the financial repression, assigned to 3.

\subsection{Principal Component Analysis}

Yi Wenfei and Ding Dan (2007) used the same eight indicators as Bandiera et al. (2000) to assess China's financial liberalization, and the financial liberalization event in the corresponding field, based on the importance of the events, which are assigned as $0.5,1,2$, using the method of gradual accumulation to get the index of each field and still use the principal component analysis method to get the comprehensive financial liberalization index. Zhuang Xiaojiu (2007) also used a similar approach to build China's financial liberalization of the annual index.

\section{Method}

On the basis of the above literature, we try to construct the CFLI (China's financial liberalization index) in the light of the predecessors' methods. In the specific method, we first select the seven indicators as a measure of China's financial liberalization process of the seven dimensions (see Table 1). In China, financial liberalization is a significant gradual process, the CFLI should be the degree of liberalization after each policy change. The advantage of gradual accumulation is that it can embody this gradual process, thus for these seven dimensions, this article use gradually cumulative method. In order to minimize the subjectivity, this paper sets out the strict assignment criteria as follows: the general event on behalf of financial liberalization is 0.5 , Major events or general policies and regulations is 1 , the implementation of major policies and regulations is 1.5 . If the occurrence of the opposite of the incident or policy of liberalization, the assignment is negative.

Table 1. CFLI assessment indicators.

\begin{tabular}{|c|c|}
\hline Indicator name & description \\
\hline $\begin{array}{l}\text { Interest rate } \\
\text { liberalization }\end{array}$ & $\begin{array}{l}\text { The government relaxes and even cancels interest } \\
\text { rate restrictions on financial institutions so that the } \\
\text { level of interest rates is determined by market } \\
\text { supply and demand. }\end{array}$ \\
\hline Credit control & $\begin{array}{l}\text { Directional or credit policy credit reduced or even } \\
\text { disappear. }\end{array}$ \\
\hline $\begin{array}{l}\text { Barriers to access } \\
\text { to the financial } \\
\text { sector }\end{array}$ & $\begin{array}{l}\text { Reduce barriers to entry, reduce restrictions on } \\
\text { business innovation in financial institutions, and } \\
\text { other measures that will help increase competition } \\
\text { in financial markets. }\end{array}$ \\
\hline $\begin{array}{l}\text { Macro prudent } \\
\text { management }\end{array}$ & $\begin{array}{l}\text { The strengthening of the independence of the central } \\
\text { bank and of the prudential supervision of financial } \\
\text { institutions. }\end{array}$ \\
\hline $\begin{array}{l}\text { Ownership of } \\
\text { financial } \\
\text { institutions }\end{array}$ & $\begin{array}{l}\text { Reduce the nationalization ratio of financial } \\
\text { institutions, increase the proportion of non-state } \\
\text { property rights. }\end{array}$ \\
\hline $\begin{array}{l}\text { Securities market } \\
\text { reform }\end{array}$ & $\begin{array}{l}\text { The reduce of the securities market by government } \\
\text { intervention and the expansion of the scale of } \\
\text { development. }\end{array}$ \\
\hline $\begin{array}{l}\text { International } \\
\text { financial } \\
\text { liberalization }\end{array}$ & $\begin{array}{l}\text { Liberalization of exchange rates, liberalization of } \\
\text { current accounts and capital accounts }\end{array}$ \\
\hline
\end{tabular}

Of course, how to define an event as a general event or a major event, or whether a statute is a general policy or a major policy, a certain degree of subjectivity is inevitable, but the method is still universal and still international on the general evaluation method. Table 2 shows the assignment of degree of development of China's financial liberalization in the following seven dimensions from $2012 \mathrm{q} 1$ to $2016 \mathrm{q} 4$.

Table 2. Quantitative Tables of China's Financial Liberalization Process.

\begin{tabular}{|c|c|c|c|c|c|c|c|}
\hline & interest & credit & entry & prudence & property & security & openness \\
\hline $2012 q 1$ & 0 & 0 & 2 & 0 & 0 & 0 & 1 \\
\hline $2012 q 2$ & 1 & 2 & 0 & 2 & 1 & 0 & 1 \\
\hline $2012 q 3$ & 1 & 0 & 4 & 0 & 1 & 2 & 1.5 \\
\hline $2012 q 4$ & 1 & 1 & 4 & 3 & 1 & 2 & 6.5 \\
\hline $2013 q 1$ & 1 & 3 & 4 & 3 & 1 & 2 & 8 \\
\hline $2013 q 2$ & 0 & 0 & 4 & 5 & 1 & 2 & 8.5 \\
\hline $2013 q 3$ & 4 & 3 & 4 & 5 & 0 & 2 & 8 \\
\hline $2014 q 1$ & 4 & 3 & 5 & 6 & 2 & 3 & 12 \\
\hline $2014 q 2$ & 2 & 3 & 5 & 6 & 2 & 3 & 14 \\
\hline $2014 q 3$ & 0 & 5 & 5 & 6 & 2 & 3 & 14 \\
\hline $2014 q 4$ & 6 & 5 & 6 & 6 & 2 & 3.5 & 13 \\
\hline $2015 q 1$ & 6 & 4 & 6 & 6 & 4 & 6 & 11 \\
\hline $2015 q 2$ & 7 & 4 & 6 & 6 & 4 & 8 & 11.5 \\
\hline $2015 q 3$ & 8 & 4 & 6.5 & 8 & 5 & 8 & 11.5 \\
\hline $2016 \mathrm{q} 1$ & 8 & 6 & 7 & 8 & 5.5 & 9 & 12 \\
\hline
\end{tabular}




\begin{tabular}{llllllll}
\hline & interest & credit & entry & prudence & property & security & openness \\
\hline $2016 \mathrm{q} 2$ & 9 & 7 & 7 & 9 & 6 & 9 & 13 \\
$2016 \mathrm{q} 3$ & 9 & 9 & 10 & 9 & 6 & 11 & 15 \\
$2016 \mathrm{q} 4$ & 9 & 9 & 10 & 11 & 6 & 12 & 15 \\
\hline
\end{tabular}

Data source: The 2012-2015 "China Financial Yearbook" Memorabilia and the People's Bank of China official website related information.

\subsection{The Empirical Process}

Based on the quantitative tables above, we have also adopted the principal component analysis (PCA) to calculate the index of China's financial liberalization. To be brief, the statistical method reduces the number of primitive indicators into a few indicators that are representative through the linear combination of the original variables so that the original indicator can illustrate the features of research objects more concentratedly and more typically. The empirical process is as follows:

The KMO value in Table 3 is 0.805 , and the Bartlett spherical test has a significance value of 0 , less than 0.05 , indicating that principal component analysis is possible.

Table 3. The test of KMO \& Bartlett.

\begin{tabular}{llll}
\hline $\begin{array}{l}\text { kaiser-meyer-olkin measure of } \\
\text { sampling adequacy }\end{array}$ & Bartlett's sphericity test & \\
\hline & $\begin{array}{l}\text { The approximate } \\
\text { chi-square }\end{array}$ & df & Sig. \\
\hline 0.805 & 192.019 & 21 & 0 \\
\hline
\end{tabular}

We use SPSS18.0 and the results shown in Table 4.

Table 4. Total variance decomposition diagram.

\begin{tabular}{lllllll}
\hline Ingredients & \multicolumn{3}{c}{ Initial eigenvalue } & & Extraction of sum of squares loaded & Accumulated \% \\
\hline & total & Variance\% & Accumulated\% & total & Variance\% & 85.759 \\
\hline 1 & 6.003 & 85.759 & 85.759 & 6.003 & 85.759 & \\
2 & 0.492 & 7.027 & 92.786 & & & \\
3 & 0.176 & 2.511 & 95.298 & & & \\
4 & 0.148 & 2.11 & 97.407 & & \\
5 & 0.121 & 1.732 & 99.14 & & \\
6 & 0.048 & 0.688 & 99.827 & & & \\
7 & 0.012 & 0.173 & 100 & & & \\
\hline
\end{tabular}

Extraction method: Principal component analysis

It can be seen from Table 4 that the cumulative contribution rate of the first principal component reaches $85.759 \%$, so it should be retained. The Scree plot can show the selection process of the principal component more clearly. In order to avoid the error, the result of the selection of the principal component should be verified by the Scree plot (Figure 1).

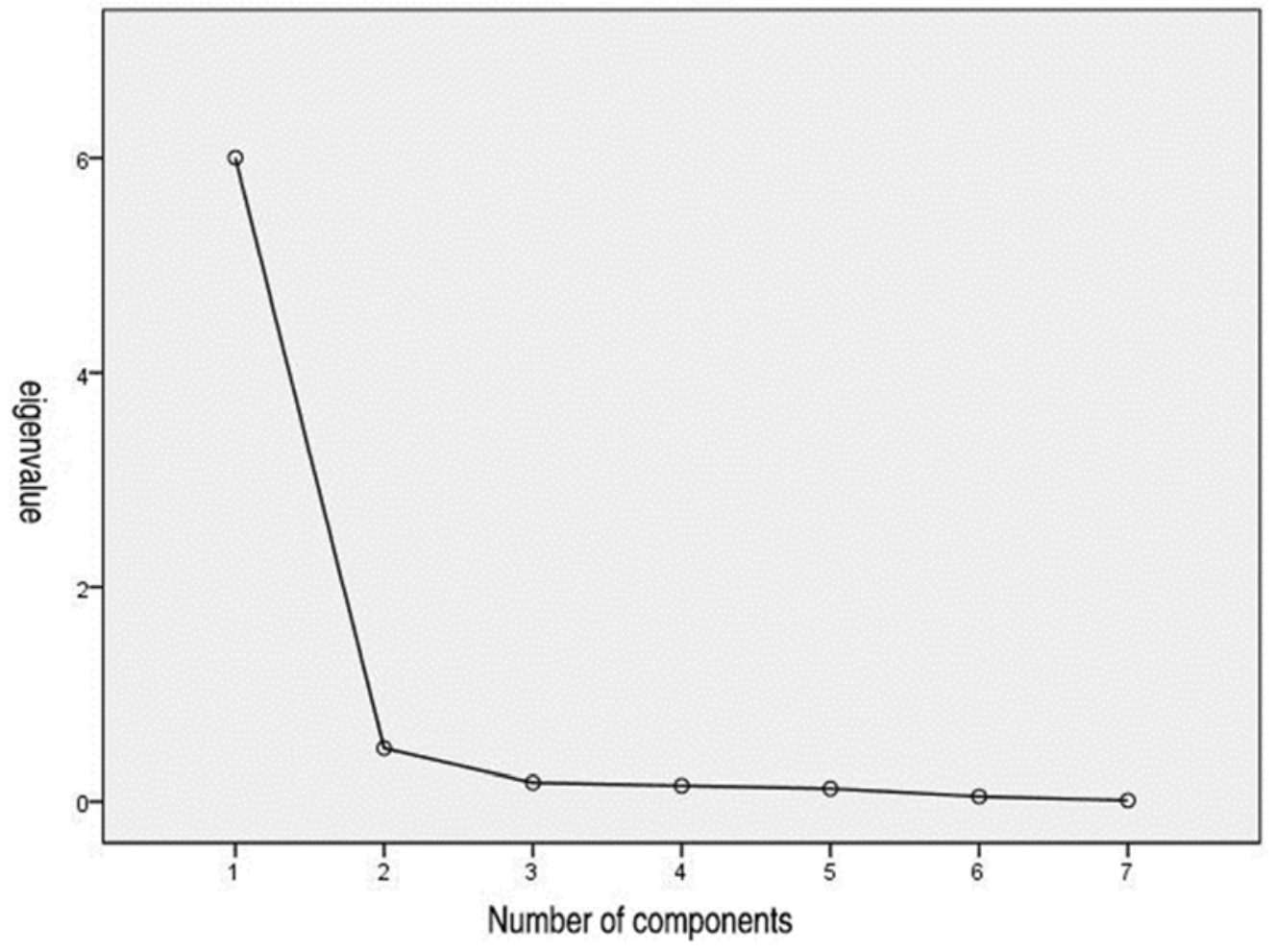

Figure 1. Scree plot. 
According to the factor matrix,

CFLI $=0.915 *$ interest $+0.928 *$ credit $+0.944 *$ entry $+0.953 *$ prudence $+0.925 *$ property $+0.962 *$ security $+0.852 *$ openness

Table 5. Factor matrix.

\begin{tabular}{ll}
\hline & Ingredients \\
\cline { 2 - 2 } & $\mathbf{1}$ \\
\hline interest & 0.915 \\
credit & 0.928 \\
entry & 0.944 \\
prudence & 0.953 \\
property & 0.925 \\
security & 0.962 \\
openness & 0.852 \\
\hline
\end{tabular}

Extraction method: Ingredients.

A. One ingredient has been extracted.

Figure 2 shows the standardized number of CFLI each quarter.

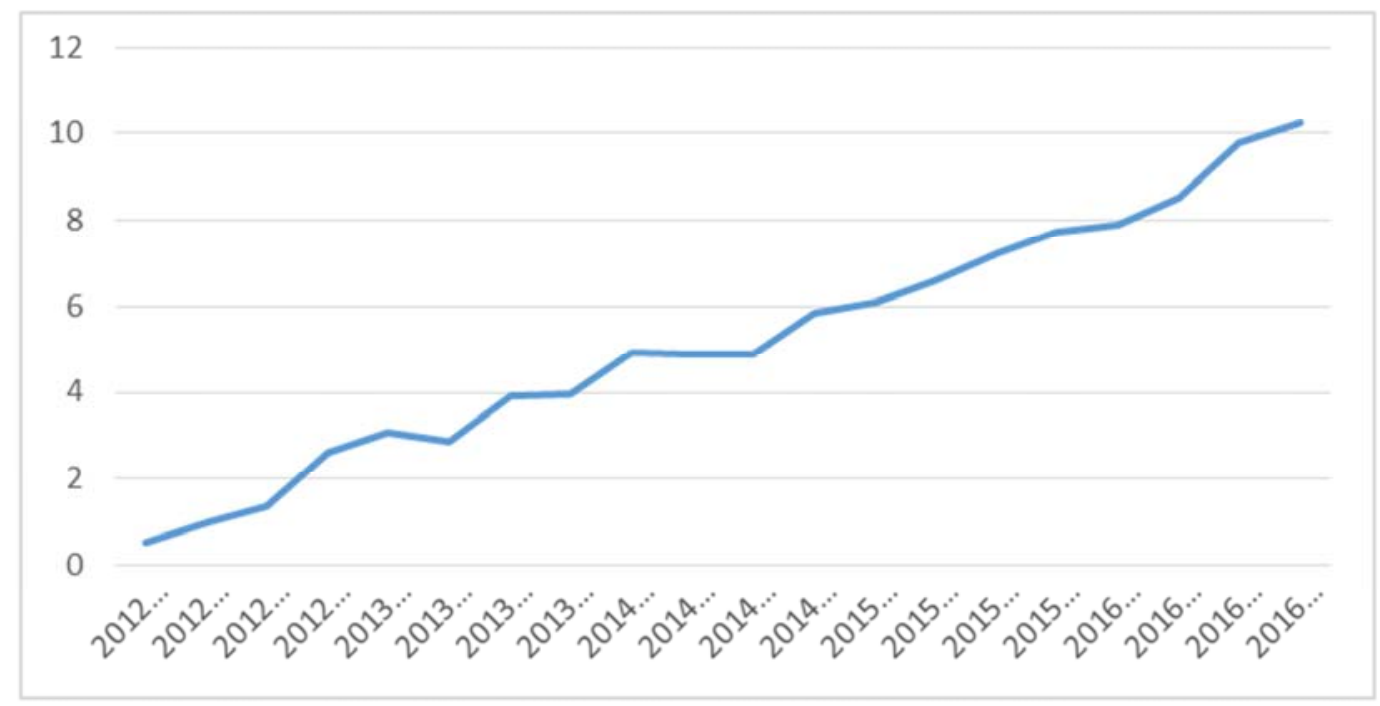

Figure 2. CFLI (2012q1-2016q4).

\subsection{Results Analysis}

It is not difficult to see from the figure above, there are twists and turns, but what the figure 2 shows is basically consistent with the development process of China's financial system.

In the case of the interest rate liberalization process, the upper limit of the floating rate range of the deposit interest rate of financial institutions has been gradually released from November 2014, and the floating rate ceiling of the term deposit is fully released for one year (excluding one year) in August 2015, In October 2015 completely liberalized the ceiling of deposit interest rates floating. It should be noted that with the liberalization of deposit interest rates, China's interest rate liberalization reform has taken a historic step, but only to achieve the basic liberalization of interest rate control, not equal to the interest rate liberalization has been completed.

Financial sector access barriers gradually reduced, the financial industry innovation in the development of norms. In
2013, the banking financial institutions actively introduce new products, new tools, new services into the fields of credit, financial management, trust, agents, investment. For another, the Internet finance springs up. "To promote the healthy development of Internet finance" was first written into the government work report in the year of 2014. Yu'E Bao, Wechat wallet, Ant Financial, Jingdong consumer finance strategy, China Minsheng Banking Corp., Ltd. (CMBC), China Merchants Bank, China Development Bank Capital, etc. to join $\mathrm{P} 2 \mathrm{P}$, the richness and availability of public financial products greatly improved.

As far as financial institution ownership is concerned, since 2012, China Postal Savings Bank has been transformed into a joint stock limited company and China Huarong Asset Management Co., Ltd. has been officially listed. The banking industry organization system is more sound, the rapid development of small and medium-sized banking financial institutions, institutional types, quantity and market share continue to rise. 2014 witnesses first batch of private bank pilot--Webank, Wenzhou Minshang Bank, MyBank, 
Shanghai Huarui Bank, Tianjin Jincheng Bank etc., which introduces a competitive mechanism into the banking industry to meet the diversified financing needs.

In the securities market reform, multi-level capital market system construction continues to advance. In 2012, China People's Insurance Group achieves overall listing in the H-share market; Futures trading scale expands rapidly; Trading participators in the foreign exchange market increases, and swaps maintain rapid growth. By the end of 2013, the pilot scheme for the transfer of shares of small and medium-sized enterprises was extended to the whole country.

As far as international financial liberalization is concerned, China has already opened its current account by the end of 1996, and capital account convertibility and liberalization of exchange rate have been considered. In 2014, the exchange rate liberalization reform further penetrates; regional financial reform pilot goes steady, covering the financial opening up, RMB capital accounts convertibility, cross-border RMB business, Guangdong, Hong Kong and Macao financial cooperation, cross-border financial cooperation. QFII, RQFII, QDII, RQDII and Shanghai-Hong Kong Stock Connect program starts; in the year of 2016, the renminbi officially joined SDR, besides, it achieves direct currency transactions with New Zealand dollar, British pound, euro, Singapore dollar etc.

\section{Conclusion}

In this paper, the definition of financial liberalization is combed and the proposed, and the method of measurement of CFLI is put forward according to the advantages and disadvantages of previous methods. The seven indicators of financial liberalization are obtained so that we construct a financial liberalization index system applicable to China, and in the past five years, almost all the major policy changes in the process of China's financial liberalization are assigned. Then we use PCA to do empirical measurement and analysis and we have got the CFLI.

It should be noted that, the definition of financial liberalization can only be measured from the level of the policy system, and the measurement of the system itself inevitably exists subjectivity on the assignment of parameters. To minimize the impact of human subjective factors on the assignment, we strictly follow the assignment criteria in practice, and strive to construct the index of this article is true; Due to the difference of initial economic conditions and political environment of each country, the order and speed of financial liberalization reform in are different, so even if the same Method to measure the financial liberalization of each country, the index we construct are not comparable. But we can see the degree and speed of the country's financial liberalization reform from the trend chart of the index, so as to further analyze the impact of financial liberalization reform on financial deepening and economic growth.

\section{References}

[1] Liu Yi, Shen Hong. Financial marketization of the measurement analysis [J]. Finance and Economics Research, 2002 (9).

[2] Wenfei Yi, Ding Dan. China's financial liberalization index design and analysis [J]. Economic Sciences, 2007 (3).

[3] Xiaojiu Zhuang. Construction of China's financial marketization index [J]. Finance Research, 2007 (11).

[4] Williamson, John and Mahar, Molli, 1998, "A Survey of Financial Liberalization" [J], Essays in International Finance, No.211, November.

[5] Montiel, P and Reinhart, C. M., 1999, "Do capital controls and macroeconomic polices influence the volume and composition of capital flows? Evidence from the 1990s". Journal of International Money and Finance 18, pp.619-635.

[6] Bandiera Oriana \& Gerard Caprio \& Patrick Honohan \& Fabio Schiantarelli, 2000, "Does Financial Reform Raise or Reduce Saving" [J], The Review if Economics and Statistics, MIT Press, vol.82(2), pages 239-263, May.

[7] Kaminsky, Graciela and Schmukler, Sergio, 2003,"Short-Run Pain, Long-Run Gain: The Effect of Financial Liberalization", International Monetary Fund, IMF Working Papers, vol.03/34.

[8] Koo Jaewoon and Sunwoo Shin, 2004, "Financial Liberalization and Corporate Investments: Evidence from Korean Firm Data", Asian Economic Journal, vol.18, issue3, pages277-292.

[9] Nicolas·Borst, Nicolas·lardy, Li Xiang. Progress of financial liberalization and financial stability of China $[\mathrm{J}]$, International Economic Review, 2015(3): 168-171.

[10] Xiaofei Liu. Financial market measure、 marketization process and economic growth of China [J], Manager' Journal, 2015(12) 68-78.

[11] Huachao Zha, Pei Ping. Chinese Financial Market Level and Measure [J], Research on Economics and Management, 2016, 37(10): 22-30.

[12] Dai Wei, Xuefang Zhang. Financial development、 financial liberalization and the efficiency of capital allocation of the real economy [J], Journal of Audit \& Economics, 2017 (1): $117-126$. 